\title{
Analisa parameter pada pemotongan plate menggunakan CNC fiber laser cutting terhadap kekasaran permukaan
}

\author{
M Arief Hidayat ${ }^{1 *}$, Akhmad Farid ${ }^{2}$, Purbo Suwandono ${ }^{3^{*}}$ \\ ${ }^{1}$ Teknik Mesin, Fakultas Teknik, Universitas Widyagama Malang \\ ${ }^{2,3} \mathrm{D} 3$ Mesin Otomotif, Fakultas Teknik, Universitas Widyagama Malang \\ Jalan borobudur No 35, Malang, Indonesia \\ *Corresponding author: purbo@widyagama.ac.id
}

\begin{abstract}
With the advancement of advanced equipment, Computer Numerical Control (CNC) laser cutting as a manufacturing tool in plate cutting, where industri player make to get maximum result. Laser cutting Cutting is one of the tools used by the industrial world to maximize cutting results. The purpose of this research To find out the results of the difference using the parameters of air pressure and cutting speed on a Q235B carbon steel plate with a thickness of $3 \mathrm{~mm}$ using CNC fiber laser cutting on the surface roughness of the material. The method used in this study is a real experimental research method and data analysis to analyze parameters on plate cutting using laser cutting on surface roughness with this number of experiments 9 and 3 replications for the research process by testing surface roughness using Surface Roughness $S j-210$ Mitutoyo. The results showed that the higher the air pressure and the lower the cutting speed, the lower the surface roughness value and vice versa. The lowest surface roughness value is at air pressure of 16 Bar with a cutting speed of 3300/min which is getting a value of $1.499 \mu \mathrm{m}$ and the highest surface roughness value is at air pressure of 12 bar with a cutting speed of $3400 \mathrm{~mm} / \mathrm{min}$ which is getting a value of 2.986 $\mu \mathrm{m}$. dengan kecepatan pemotongan $3400 \mathrm{~mm} / \mathrm{min}$ yaitu mendapatkan nilai sebesar 2,986 $\mu \mathrm{m}$.
\end{abstract}

Keyword: Laser Cutting, air pressure, cutting speed, surface rougness.

\begin{abstract}
Abstrak
Dengan kemajuan alat-alat canggih, Computer Numerical Control (CNC) laser cutting sebagai alat manufaktur pada pemotongan plat, dimana pelaku industri didorong untuk mendapatkan hasil yang maksimal. Pemotongan laser cutting adalah salah satu alat yang digunakan dunia industri untuk memaksimalkan hasil pemotongan. Tujuan penelitian ini Untuk mengetahui hasil perbedaan menggunakan parameter tekanan udara dan kecepatan pemotongan pada plate carbon steel Q235B dengan tebal $3 \mathrm{~mm}$ menggunakan CNC fiber laser cutting terhadap kekasaran permukaan material. Metode yang digunakan di dalam penelitian ini adalah metode penelitian experimental nyata dan analisa data untuk menganalisa parameter pada pemotongan pelat menggunakan laser cutting terhadap kekasaran permukaan dengan jumlah eksperimen ini 9 dan 3 kali replikasi untuk proses penelitian dengan pengujian keksaran permukaan menggunakan Surface Roughness $\mathrm{Sj}-210$ Mitutoyo. Hasil Penelitian menunjukkan bahwa semakin tinggi tekanan udara dan semakin rendah kecepatan pemotongan maka nilai kekasaran permukaan semakin rendah begitupun sebaliknya. Nilai kekasaran permukaan paling rendah berada pada tekanan udara 16 Bar dengan kecepatan pemotongan 3300/min yaitu mendapatkan nilai sebesar 1,499 $\mu \mathrm{m}$ dan nilai kekasaran permukaan tertinggi berada pada tekanan udara 12 bar dengan kecepatan pemotongan $3400 \mathrm{~mm} / \mathrm{min}$ yaitu mendapatkan nilai sebesar 2,986 $\mu \mathrm{m}$.
\end{abstract}

Kata Kunci: Laser Cutting, tekanan udara, kecepatan pemotongan, kekasaran permukaan. 


\section{Pendahuluan}

Perkembangan dunia industri yang semakin maju mendorong para pelaku dunia industri untuk meningkatkan kebutuhan akan alat-alat yang lebih efektif dan efisien. Dengan kemajuan alat-alat canggih, pelaku industri didorong untuk mendapatkan hasil yang maksimal. Pemotongan laser adalah salah satu alat yang digunakan dunia industri untuk memaksimalkan hasil potongan. Pemotongan dengan laser merupakan proses pemotongan menjadi lebih bagus dan efisien dengan hasil keuntungan yang lebih besar dalam hal kecepatan potong. Mesin Laser Cutting yang banyak digunakan dalam dunia industri untuk Proses Pemotongan Plat logam dan dapat mengatasi ketidak mampuan proses dari mesin - mesin konvensional biasa. Media potong yang digunakan laser cutting adalah sinar laser yang dibantu dengan gas cutting yang berfungsi sebagai media pemotongan metal [1].

Masalah yang sering terjadi dalam proses laser cutting adalah kecacatan pemotongan.kecacatan tersebut diantaranya surface kasar sampai tidak terpotongnya produk pada proses pemotongan. Untuk mencapai hasil pemotongan dengan kekasaran minimum akan mempengaruhi laju pemotongan yaitu waktu yang lebih lama. Tetapi jika waktu pemotongan semakin cepat menyebabkan nilai kekasaran yang tinggi dikarenakan sinar laser yang terlalu cepat untuk memotong material. Untuk mendapatkan hasil produk dengan kekasaran minimum dapat dicapai dengan pengaturan parameter yang mempengaruhi, yaitu titik fokus sinar laser, tekanan gas cutting, dan cutting speed [2]

Duriska di tahun 2011 melakukan penelitian pengaruh variasi tekanan gas potong dan cutting speed pada laser cutting terhadap kekasaran permukaan baja SS400. Berdasarkan penelitian yang telah dilakukan bahwa peneliti bertujuan untuk meneliti tentang variasi tekanan gas potong dengan bermacam - macam variasi diantaranya yaitu 1 Bar, 1,5 Bar, 2 Bar dan variasi cutting speed $1 \mathrm{v} / \mathrm{min}, 1,5 \mathrm{v} / \mathrm{min}, 2$ v/min lalu dicari tingkat optimal dari variasi pemakaian gas cutting dan cutting speed tersebut, dengan harapan agar permukaan hasil potong tidak kasar dan gas potong yang digunakan juga menjadi lebih hemat. Dimana penelitian ini memberikan hasil bahwa tekanan gas potong dan cutting speed berpengaruh secara nyata terhadap kekasaran permukaan [3]

Penelitian yang dilakukan oleh Dhrupal melakukan penelitian tentang analisa parameter pada pemotongan pelat SS - 304 dengan menggunakan mesin laser cutting. Hasil penelitian diperoleh variasi daya laser, kecepatan potong, dan tekanan gas memberikan pengaruh terhadap kekasaran permukaan dan lebar garitan. Nilai parameter yang dioptimalkan ditemukan dengan daya $500 \mathrm{~W}$, tekanan gas 15 bar dan kecepatan potong $2000 \mathrm{~mm}$ / menit untuk nilai kekasaran permukaan minimum 4,39939 $\mu \mathrm{m}$ dan lebar garitan atas 283,688 $\mu \mathrm{m}$. Berdasarkan hasil ini, diperkirakan akan meningkatkan kualitas potongan dan menjadi pemotongan dengan hasil yang efisien [4].

\section{Tinjauan Pustaka}

\section{Laser Cutting}

Laser cutting adalah proses pemotongan yang memanfaatkan sinar laser, Laser cutting bekerja dengan mengarahkan output laser daya tinggi melalui nozzle ke materi di area lokal. CNC (Computer Numerical Control) digunakan untuk mengarahkan sinar laser yang dihasilkan, sehingga sering juga disebut CNC Laser Cutting. Laser komersial untuk pemotongan material menggunakan motion control system untuk mengikuti CNC atau G-code dari pola yang akan dipotong pada material. merupakan salah satu proses yang sering digunakan sebagai proses sebagai alternative dari permesinan konvensional. Kelebihan dari laser cutting adalah mempunyai hasil potongan yang memiliki kualitas baik dan mencegah kecacatan produk yang dihasilkan. Mesin laser cutting memiliki 
kepresisian intensitas yang tinggi dalam pemotongan logam, selain itu laser cutting dalam dunia manufaktur dapat digunakan untuk memotong berbagai macam jenis material seperti logam, kayu, kaca, dan plastic [5].

\section{Prinsip Kerja Laser Cutting}

Laser cutting bekerja dengan mengarahkan output dari daya laser tertinggi pada material yang akan dipotong kemudian meleleh, terbakar, menguap oleh gas dan meninggalkan tepi dengan permukaan yang berkualitas tinggi akibat pengaruh dari tekanan gas yang di berikan.

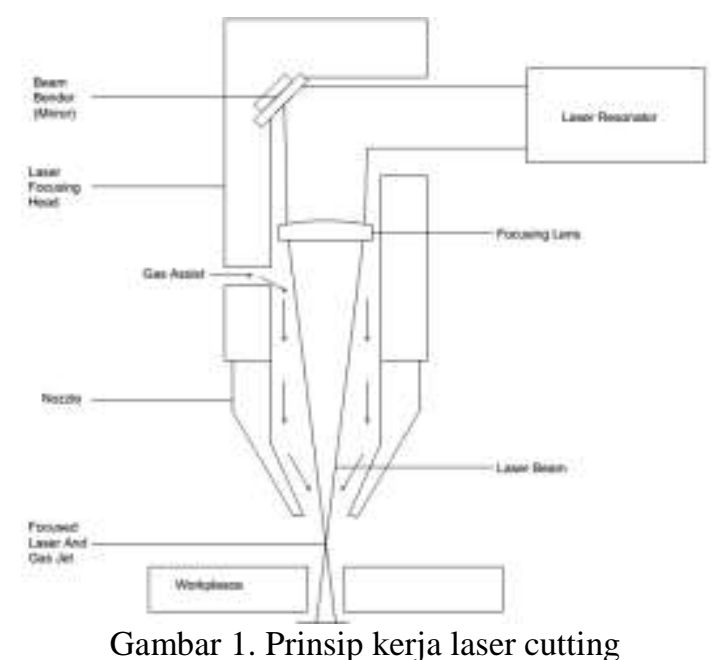

1. Resonator laser mengeluarkan sinar laser dengan diameter kurang lebih $3 / 4$ inchi.

2. Sinar laser yang dikeluarkan selanjutnya dibelokkan oleh lensa pembias sehingga sinar laser terpancar sesuai jalurnya tanpa mengalami sudut penyimpangan.

3. Sinar laser diarahkan ke lensa fokus yang akan mengkonsentrasikan laser itu.

4. Laser yang sudah berhasil terkonsentrasi selanjutnya akan dikeluarkan melalui kompenen nozzle berbarengan dengan jet gas yang bertekanan.

5. Sinar laser dan jet gas akan secara otomatis bekerja memotong benda kerja sesuai pola yang diperintahkan oleh sistem CNC.

\section{Parameter Laser Cutting}

Parameter pada pemotongan menggunakan laser cutting yaitu tekanan gas cutting dan kecepatan potong yang memiliki konstribusi dalam mengurangi variasi dari respon kekasaran dan tekanan gas cutting memiliki konstribusi paling besar sekitar 50\%. Sedangkan kecepatan potong memiliki konstribusi yang signifikan dalam mengurangi variasi dari respon kekasaran. Nilai kekasaran yang dicari akan mempengaruhi nilai laju pemotongan. Laju pemotongan yang tidak tepat akan menghasilkan produk yang kurang presisi. Laju pemotongan pada mesin CNC laser cutting merupakan fungsi dari sinar laser dalam melelehkan material saat proses pemotongan. Pada mesin CNC laser cutting laju pemotongan didapatkan berdasarkan banyaknya material yang terbuang atau leleh dalam satuan waktu. Untuk mencari banyaknya yang terbuang didapat dari fungsi pengurangan antara volume sisa dari produk dengan volume produk yang didapat persatuan waktu (waktu actual pengerjaan) [1].

\section{Kekasaran Permukaan}

Lebih mendalam mengenai kekasaran permukaan suatu material, kekasaran permukaan merupakan suatu hal yang sangat penting bagi suatu material. Hal ini dikarenakan material yang nantinya akan dijadikan suatu komponen harus memiliki suatu nilai kekasaran tertentu agar dapat sesuai dengan fungsi komponennya. Kekasaran permukaan didefinisikan sebagai ketidakaturan konfigurasi permukaan pada suatu benda atau bidang. Konfigurasi permukaan yang dihasilkan dari proses pemesinan adalah kontur permukaan yang berbentuk berupa kawahkawah kecil pada permukaan. Kondisi kawah yang dihasilkan pada proses pemesinan EDM sinking tergantung pada energi listrik yang terdapat pada setiap loncatan bunga api listrik [6]. 


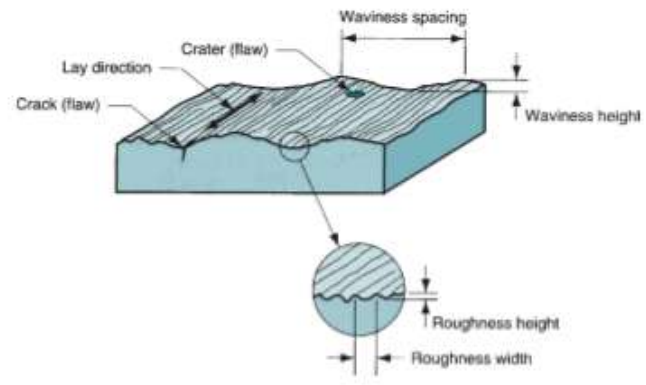

Gambar 2. Surface texture features

Tekstur permukaan seperti yang ditampilkan pada gambar 1 terdiri dari penyimpangan acak yang berulang pada permukaan normal dari suatu obyek permukaan. Kekasaran mengacu pada jarak penyimpangan dari permukaan yang nominal yang ditentukan oleh karakteristik material dan cara memproses hingga diperoleh bentuk permukaan itu. Waviness menggambarkan besar penyimpangan pengaturan jarak sayatan saat pengerjaan, kondisi ini dapat diakibatkan oleh getaran, lenturan, perlakuan panas dan factor lain. Kekasaran permukaan adalah karakteristik terukur yang mengacu pada penyimpangan kekasaran sebagaimana uraian di atas. Permukaan akhir (surface finish) adalah suatu istilah hubungan yang mencerminkan kehalusan atau mutu umum suatu permukaan [7].

Kekasaran permukaan (Parameter Surface Roughness) dapat diukur dengan menggunakan alat sensor (stylus), sensor (stylus) harus digerakan mengikuti suatu lintasan berupa garis lurus dengan jara yang telah ditentukan. Panjang lintasan disebut dengan panjang suatu pengukuran (traversing length). Sesaat sebelum jarum bergerak dan sesaat sebelum jarum berhenti disitu alat ukur melakukan perhitungan berdasarkan data yang terdeteksi oleh jarum peraba alat ukur [8]. Bagian permukaan yang terbaca oleh sensor alat ukur disebut panjang sempel. Parameter permukaan yang berhubungan dengan dimensi diketahui parameternya seperti berikut:
1. Kedalaman Total (Peak To Vallery), $\mathrm{R}_{\mathrm{t}}$

Kedalaman total adalah besarnya jarak dari profil referensi sampai dengan profil dasar. Satuannya adalah dalam satuan micron $(\mu \mathrm{m})$.

2. Kedalaman Perataan (Peak To Mean Line), $\mathrm{R}_{\mathrm{p}}$

Kedalaman perataan $\left(R_{p}\right)$ adalah jarak rata-rata dari profil referensi sampai dengan profil terukur. Apabila dikatakan juga bahwa kedalaman perataan merupakan jarak antara profil tengah dengan profil referensi.

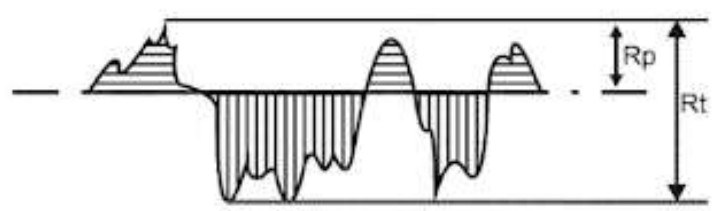

Gambar 3. Kedalaman total dan kedalaman perataan

3. Kekasaran Rata-Rata Aritmetis (mean roughness indec/center line average, CLA), $\mathrm{R}_{\mathrm{a}}$

Kekasaran rata-rata aritmetis adalah harga rata-rata aritmatik dari harga absolut jarak antara profil terukur dengan profil tengah.

$\mathrm{Ra}=\frac{1}{s} \int_{0}^{1} h i^{2} \cdot d x(\mu m)$

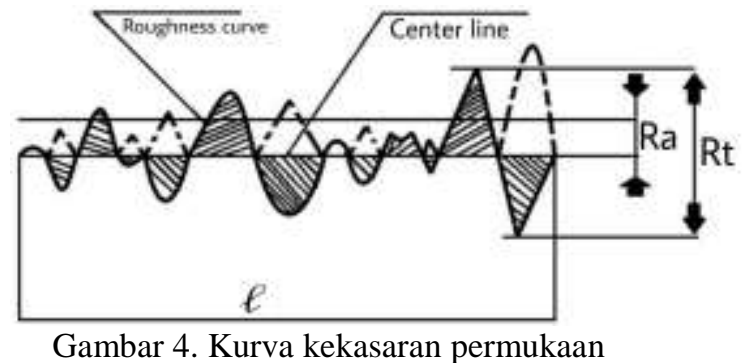

Metode Penelitian

Metode yang digunakan di dalam penelitian ini adalah metode penelitian experimental nyata dan analisa data untuk menganalisa parameter pada pemotongan pelat Baja Karbon Q235B menggunakan laser cutting terhadap kekasaran permukaan dengan jumlah eksperimen ini 9 dan 3 kali replikasi untuk proses penelitian. 


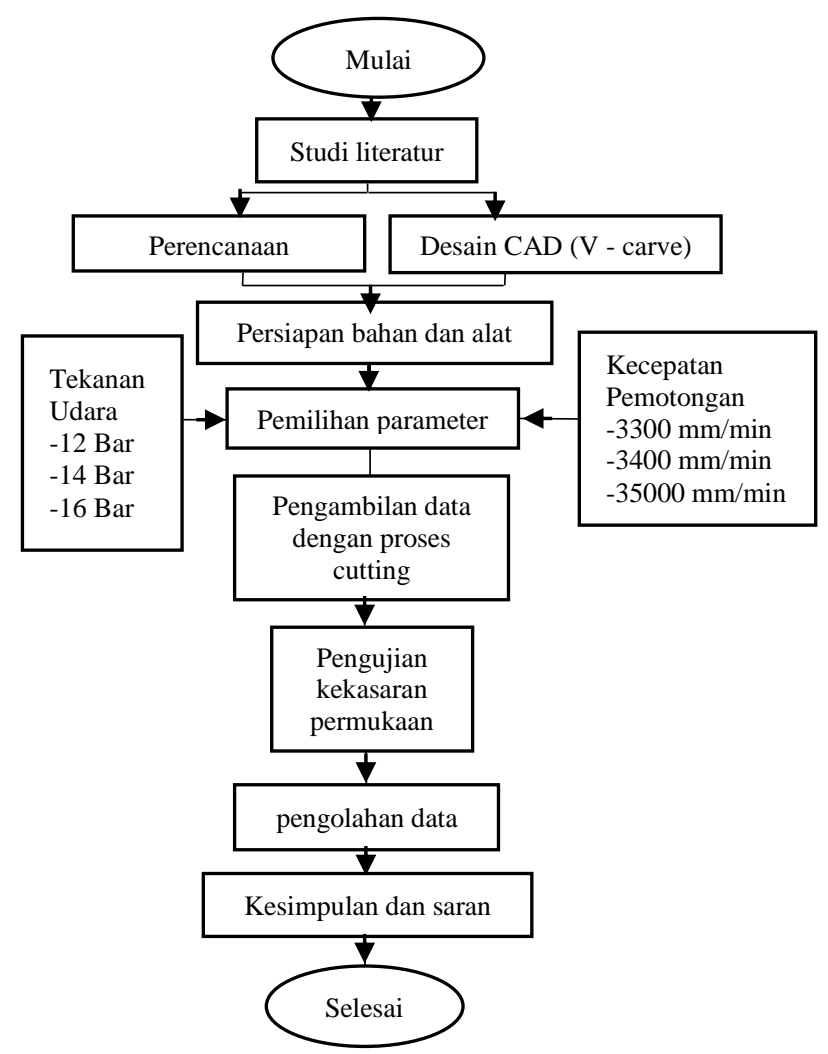

Gambar 5. Diagram alir penelitian

Didalam penelitian ini menggunakan variabel yang dipergunakan, antara lain :

Variabel bebas, dalam penelitian ini adapun varibel bebas atau parameter yang akan kita gunakan tekanan gas dan kecepatan pemotongan. Dalam penelitian ini variabel terikatnya menggunakan variasi parameter, metode ini akan menguji kekasaran permukaan material. Pada penelitian ini menggunakan titik fokus sinar laser sebagai variabel terkontrol.

Bahan yang digunakan dalam penelitian ini adalah plat carbon steel Q235B dengan tebal $3 \mathrm{~mm}$ dengan kandungan carbon (C) $0,20 \%$, silicon $(\mathrm{Si})$ $0.35 \%$, Mangan (Mn) 1,40\%, Phosphorus (P) $0,045 \%$, Sulfur (S) $0,045 \%$ baja ini termasuk dalam kategori baja karbon rendah. Pada penelitian ini menggunakan alat potong fiber laser cutting Raycus $2000 w$.

Variasi tekanan udara 12 Bar, 14 Bar, 16 Bar sedangkan variasi kecepatan pemotongan $3300 \mathrm{~mm} / \mathrm{min}, 3400 \mathrm{~mm} / \mathrm{min}$, $3500 \mathrm{~mm} / \mathrm{min}$. Setelah dilakukan proses pemotongan menggunakan variasi parameter tersebut selanjutnya dilakukan tahap uji kekasaran permukaan dengan berikut.

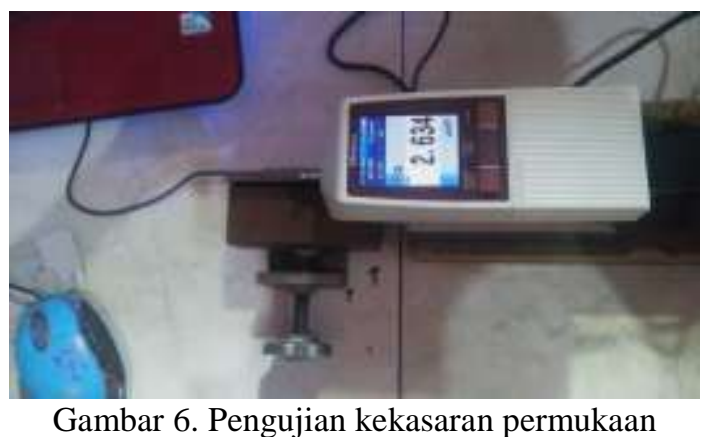

Pengujian kekasaran permukaan di lakukan menggunakan Surface Roughness SJ - 210 Mitutoyo pengujian dilakukan dengan cara mengambil data sebanyak tiga titik pada spesimen untuk mencari rata rata nilai kekasaran permukaa pada spesimen.

\section{Hasil dan Pembahsan}

Foto spesimen yang akan diuji kekasaran permukaannya dengan menggunakan surface roughness SJ - 210 sebanyak sembilan macam spesimen dengan parameter tekanan udara dan kecepatan pemotongan yang berbeda.

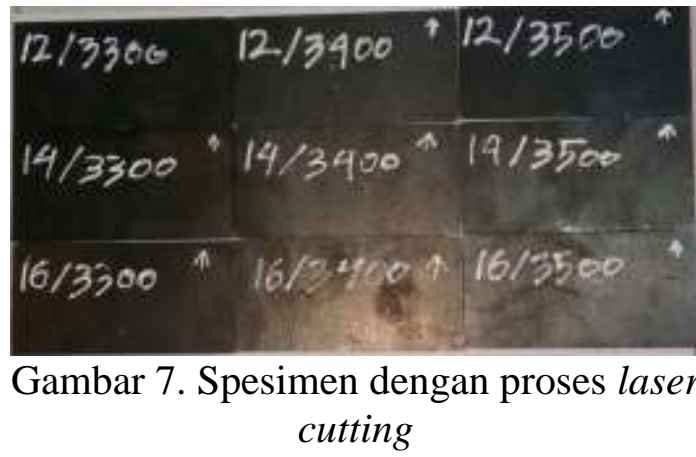

Gambar 7 dengan angka 12, 14, 16 diartikan sebagai tekanan udara (Bar) dan angka 3300, 3400, 3500 diartikan sebagai kecepatan pemotongan $(\mathrm{mm} / \mathrm{min})$ dimana variasi tekanan udara dan variasi kecepatan pemotongan memiliki konstribusi dalam mengurangi variasi dari respon kekasaran permukaan. 


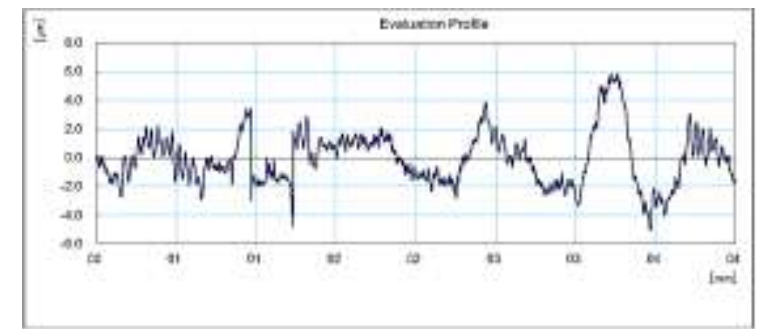

Gambar 8. Kurva kekasaran titik 3

Gambar diatas menunjukan bentuk kurva hasil dari pengujian kekasaran permukaan pada spesimen ke tujuh di posisi titik ke 3 menggunakan tekanan udara 16 Bar dengan kecepatan pemotongan $3300 \mathrm{~mm} / \mathrm{min}$ mempunyai nilai sebesar $1,466 \mu \mathrm{m}$.

Berdasarkan data pengujian, didapatkan nilai rata - rata kekasaran permukaan setiap variasi kecepatan pemotongan dengan tekanan udara yang sama.

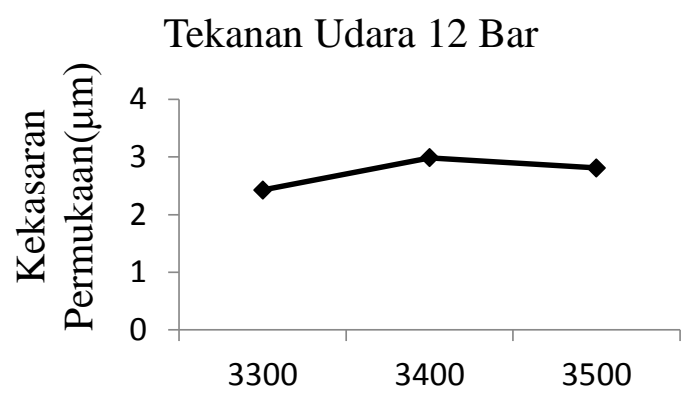

Kecepatan pemotongan $(\mathrm{mm} / \mathrm{min})$

Gambar 9. Nilai kekasaran permukaan pada tekanan 12 Bar dan kecepatan pemotongan $3300 \mathrm{~mm} / \mathrm{min}$, $3400 \mathrm{~mm} / \mathrm{min}, 3500 \mathrm{~mm} / \mathrm{min}$.

Grafik nilai kekasaran permukaan pada tekanan udara 12 Bar dengan kecepatan pemotongan $3300 \mathrm{~mm} / \mathrm{min}, 3400$ $\mathrm{mm} / \mathrm{min} 3500 \mathrm{~mm} / \mathrm{min}$, maka didapatkan nilai rata-rata kekasaran permukaan ketiganya yaitu $2,425 \mu \mathrm{m}, 2,986 \mu \mathrm{m}$ dan $2,809 \mu \mathrm{m}$. Jadi tekanan udara 12 Bar pada variasi kecepatan pemotongan 3400 $\mathrm{mm} / \mathrm{min}$ dan $3500 \mathrm{~mm} / \mathrm{min}$ tidak menggambarkan perbedaan yang terlalu jauh, dikarenakan peningkatan kecepatan pemotongan $3400 \mathrm{~mm} / \mathrm{min}$ dan 3500 $\mathrm{mm} / \mathrm{min}$ menimbulkan reaksi eksotermik dari daya laser yang kurang maksimal sehingga menghasilkan kekasaran permukaan lebih tinggi terutama pada tekanan udara yang rendah mengakibatkan proses pembakaran yang kurang maksimal.

Hasil percobaan ini menunjukkan bahwa penggunaan kecepatan pemotongan $3300 \mathrm{~mm} / \mathrm{min}$ memberikan hasil pembakaran yang sempurna dibandingkan kecepatan pemotongan $3400 \mathrm{~mm} / \mathrm{min}$ dan $3500 \mathrm{~mm} / \mathrm{min}$ sehingga menimbulkan kekasaran permukaan yang lebih rendah.

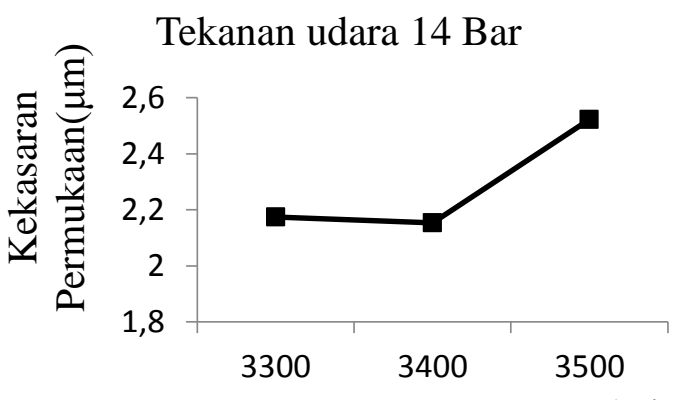

Kecepatan pemotongan $(\mathrm{mm} / \mathrm{min})$

Gambar 10. Nilai kekasaran permukaan pada tekanan 14 Bar dan kecepatan pemotongan 3300 $\mathrm{mm} / \mathrm{min}, 3400 \mathrm{~mm} / \mathrm{min}, 3500 \mathrm{~mm} / \mathrm{min}$.

Grafik nilai kekasaran permukaan pada tekanan udara 14 Bar dengan kecepatan pemotongan $3300 \mathrm{~mm} / \mathrm{min}, 3400$ $\mathrm{mm} / \mathrm{min} 3500 \mathrm{~mm} / \mathrm{min}$, maka didapatkan nilai rata-rata kekasaran permukaan ketiganya yaitu $2,175 \mu \mathrm{m}, 2,154 \mu \mathrm{m}$ dan 2,523 $\mu \mathrm{m}$. Jadi tekanan udara 14 Bar pada variasi kecepatan pemotongan 3300 $\mathrm{mm} / \mathrm{min}$ dan $3400 \mathrm{~mm} / \mathrm{min}$ tidak menggambarkan perbedaan yang terlalu jauh di bandingkan dengan kecepatan pemotongan $3500 \mathrm{~mm} / \mathrm{min}$, dikarenakan peningkatan kecepatan pemotongan 3500 $\mathrm{mm} / \mathrm{min}$ menimbulkan reaksi eksotermik dari daya laser yang kurang maksimal sehingga proses pembakaran yang terjadi menjadi kurang sempurna di bandingkan kecepatan pemotongan $3300 \mathrm{~mm} / \mathrm{min}$ dan $3400 \mathrm{~mm} / \mathrm{min}$ yang didukung tekanan udara cukup besar (14 Bar) sehingga menghasilkan nilai kekasaran permukaan lebih rendah.

Hasil percobaan ini menunjukkan bahwa penggunaan kecepatan pemotongan $3300 \mathrm{~mm} / \mathrm{min}$ dan $3400 \mathrm{~mm} / \mathrm{min}$ memberikan hasil pembakaran yang sempurna dibandingkan kecepatan pemotongan $3500 \mathrm{~mm} / \mathrm{min}$ sehingga 
menimbulkan kekasaran permukaan yang lebih rendah.

Tekanan udara 16 Bar

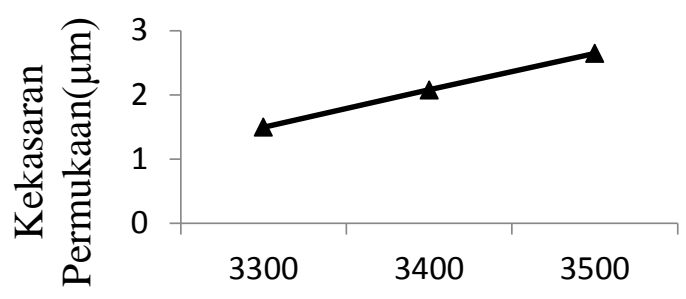

Kecepatan pemotongan $(\mathrm{mm} / \mathrm{min})$

Gambar 11. Nilai kekasaran permukaan pada tekanan 14 Bar dan kecepatan pemotongan 3300 $\mathrm{mm} / \mathrm{min}, 3400 \mathrm{~mm} / \mathrm{min}, 3500 \mathrm{~mm} / \mathrm{min}$

Grafik nilai kekasaran permukaan dengan tekanan udara 16 Bar dan kecepatan potongan $3300 \mathrm{~mm} / \mathrm{min}, 3400 \mathrm{~mm} / \mathrm{min}$ $3500 \mathrm{~mm} / \mathrm{min}$ dan pada proses laser cutting. Maka didapatkan nilai rata-rata kekasaran permukaan ketiganya yaitu $1,499 \mu \mathrm{m}, 2,077 \mu \mathrm{m}$ dan 2,645 $\mu \mathrm{m}$. Jadi tekanan udara 16 Bar pada variasi kecepatan pemotongan $3300 \mathrm{~mm} / \mathrm{min}$ menghasilkan nilai kekasaran permukaan lebih rendah dibandingkan kecepatan pemotongan $3400 \mathrm{~mm} / \mathrm{min}$ dan 3500 $\mathrm{mm} / \mathrm{min}$, pada tekanan 16 Bar mengalami perbedaan yang signifikan dikarenakan kecepatan pemotongan $3300 \mathrm{~mm} / \mathrm{min}$ lebih memberikan reaksi eksotermik dari daya laser yang sempurna dengan di dukungnya tekanan udara yang besar terhadap pembakaran material.

Hasil percobaan ini menunjukkan bahwa penggunaan tekanan udara 16 Bar dengan kecepatan pemotongan 3300 $\mathrm{mm} / \mathrm{min}$ lebih memberikan hasil kekasaran permukaan yang rendah.

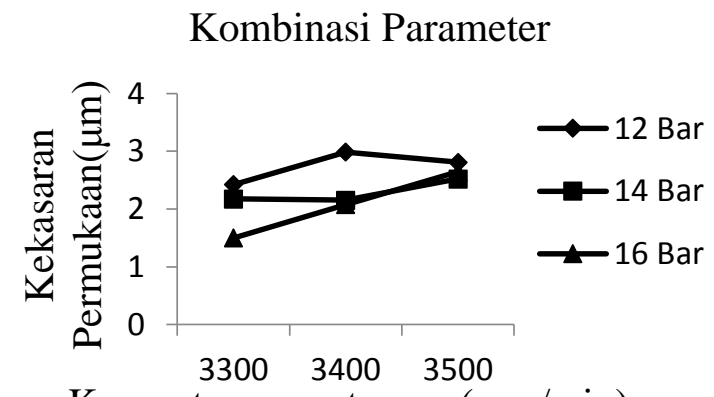

Kecepatan pemotongan $(\mathrm{mm} / \mathrm{min})$
Pada gambar di atas menjelaskan bahwa perbedaan tekanan udara dan kecepatan pemotongan sangat berpengaruh terhadap kekasaran permukaan. Peningkatan tekanan udara 16 Bar memberi pengaruh yang signifikan terhadap kualitas pemotongan dimana efek terhadap penurunan nilai kekasaran permukaan hal ini disebabkan ketika tekanan udara yang tinggi mulai meniup lelehan yang dihasilkan dari reaksi eksotermik dari daya laser itu sendiri, serpihan yang di hasilkan dengan cepat terbuang ke bawah sehingga tidak mengenai permukaan yang akan di potong sedangkan tekanan udara yang rendah 12 Bar tidak cepat meniup lelehan yang dihasilkan dari reaksi eksotermik dan tidak menghasilkan jumlah panas yang lebih tinggi dari yang dibutuhkan sehingga proses pembakaran tidak maksimal ketika melakukan proses pemotongan.

Kecepatan pemotongan 3500 $\mathrm{mm} / \mathrm{min}$ yang dinilai tinggi juga mengakibatkan suhu yang lebih rendah akan menghasilkan viskositas lelehan lebih rendah dan kecepatan pemotongan 3300 $\mathrm{mm} / \mathrm{min}$ di niali lebih rendah juga mengakibatkan suhu lebih tinggi dibandingkan kecepatan pemotongan 3400 $\mathrm{mm} / \mathrm{min}$ dan $3500 \mathrm{~mm} / \mathrm{min}$. Pengaturan parameter dengan meningkatkan tekanan udara 16 Bar dan menurunkan kecepatan pemotongan $3300 \mathrm{~mm} / \mathrm{min}$ terbukti berpengaruh secara signifikan memberikan hasil nilai kekasaran permukaan lebih rendah yaitu sebesar 1,499 $\mu \mathrm{m}$ dibandingkan tekanan udara 12 Bar dan 14 Bar yang memberikan nilai kekasaran permukaan cukup tinggi.

Nilai kekasaran permukaan $(\mathrm{Ra})$ $1,499 \mu \mathrm{m}$ merupakan nilai kekasaran permukaan paling rendah dengan menggunakan tekanan udara 16 Bar dan kecepatan pemotongan $3300 \mathrm{~mm} / \mathrm{min}$. Sedangkan nilai kekasaran permukaan tertinggi sebesar $2,986 \mu \mathrm{m}$ dengan menggunakan tekanan udara 12 Bar dan kecepatan pemotongan $3400 \mathrm{~mm} / \mathrm{min}$. Dari grafik diatas 4.20 penggunaan tekanan udara 16 Bar dengan pada kecepatan yang

Gambar 12. Kombinasi Parameter 
sama $3300 \mathrm{~mm} / \mathrm{min}$ menghasilkan nilai kekasaran permukaan lebih rendah dibandingan dengan tekanan udara $12 \mathrm{Bar}$ dan 14 Bar yang lebih tinggi.

Dikarenakan saat terjadinya proses pemotongan, di dukungnya daya laser yang tinggi dan tekanan udara yang semakin tinggi akan mengoksidasi pada material (logam) yang akan dipotong sehingga lelehan dari garitan dengan mudah dihilangkan dengan udara yang bertekanan akan meniup lelehan yang sudah tereaksi eksotermik dari cahaya sinar laser yang keluar secara bersamaan dari bagian tengah lubang nozzle, dengan daya laser tinggi tekanan udara memiliki pengaruh yang signifikan terhadap proses pemotongan pada kekasaran permukaan. Selain itu pada proses pemotongan kecepatan pemotongan memiliki dampak yang nyata. Ada perubahan nyata dalam kinerja proses saat tingkat kecepatan pemotongan ditingkatkan terhadap kekasaran permukaan yang lebih tinggi diperoleh pada saat proses pemotongan yang lebih cepat. Kehilangan daya yang tinggi dari zona pemotongan ke bahan material ketika dilakukan pemotongan dengan kecepatan tinggi menghasilkan suhu leleh yang lebih rendah dan viskositas lelehan yang tinggi karena ketergantungan suhu pada viskositas [9].

Dapat disimpulkan bahwa dari hasil penelitian yang telah dilakukan pemotongan plate carbon steel Q235B menggunakan proses laser cutting yang menghasilkan nilai kekasaran permukaan paling rendah menggunakan parameter tekanan udara 16 Bar dan kecepatan pemotongan $3300 \mathrm{~mm} / \mathrm{min}$. Hal ini menunjukkan bahwa hasil pemotongan dipengaruhi oleh parameter tekanan udara dan kecepatan pemotongan pada ketebalan plat yang tepat. Sedangkan kualitas hasil pemotongan dapat dilihat dari kekasaran permukaan, pelelehan sisi, kedataran permukaan dan material yang harus terbuang [10].

\section{Kesimpulan}

Berdasarkan penelitian yang telah dilakukan pada jumlah keseluruhan 9 spesimen digunakan sebagai uji kekasaran permukaan dengan variasi tekanan udara dan variasi kecepatan pemotongan dapat disimpulkan sebagai berikut : Hasil dari perbedaan variasi tekanan udara dan variasi kecepatan pemotongan terhadap kekasaran permukaan yaitu, nilai kekasaran permukaan paling rendah berada pada tekanan udara 16 Bar dengan kecepatan pemotongan 3300/min yaitu mendapatkan nilai sebesar 1,499 $\mu \mathrm{m}$ dan nilai kekasaran permukaan tertinggi berada pada tekanan udara 12 bar dengan kecepatan pemotongan $3400 \mathrm{~mm} / \mathrm{min}$ yaitu mendapatkan nilai sebesar $2,986 \mu \mathrm{m}$.

\section{Referensi}

[1] Dewinta, F. Y. (2017). Optimasi Parameter Mesin Laser Cutting Terhadap Kekasaran Dan Laju Pemotongan Pada Alumunium 5083 Menggunakan Desain Eksperimen Taguchi Grey Analysis Method (Doctoral Dissertation, Politeknik Perkapalan Negeri Surabaya).

[2] Anonimous. (2010a) 'Operator Manual Laser Cutting', Trumpf,Jerman.

[3] Duriska, P. (2011). Pengaruh Variasi Tekanan Gas Potong Dan Cutting Speed Pada Laser Cutting Terhadap Kekasaran Permukaan Baja Ss400 (Doctoral Dissertation, Universitas Brawijaya).

[4] Kotadiya, D. J., Kapopara, J. M., Patel, A. R., Dalwadi, C. G., \& Pandya, D. H. (2018). Parametric Analysis Of Process Parameter For Laser Cutting Process On Ss304. Materials Today: Proceedings, 5(2), 5384-5390.

[5] Prihadianto, B. D., \& Nugroho, G. (2018). Pengaruh Jarak Laser Head Terhadap Diameter Spot Pada Pemotongan Polymethyl 
Methacrylate Menggunakan Mesin Laser Cutting. Jurnal Infotekmesin Vol, 9(1).

[6] Kurniawan, Z., Yudo, E., \& Rosmansyah, R. (2018). Optimasi Kekasaran Permukaan Pada Material Amutit Dengan Proses Cnc Turning Menggunakan Desain Taguchi. Manutech: Jurnal Teknologi Manufaktur, 10(01), 45-51.

[7] Karmin, K., Ginting, M., \& Yunus, M. (2013).Analisa Kekasaran Permukaan Hasil Proses Pengampelasan Terhadap Logam Dengan Perbedaan Kekerasan. Austenit, 5(2).

[8] Ashar, M. C., Hendra, E., \& Hoten, H. V. (2014). Analisa Kekasaran Permukaan Benda Kerja Dengan Variasi Jenis Material Dan Pahat Potong (Doctoral Dissertation, Universitas Bengkulu).

[9] Lan, H., Wang, W., Shangguan, Y., \& Lin, S. (2011, August). Fundamental Studies On High Power Fiber Laser Cutting Performance Of $30 \mathrm{Mm}$ Thick Carbon Steel Plate. In Proceedings $\quad$ of $2011 \quad$ 6th International Forum On Strategic Technology (Vol. 1, Pp. 6-11). Ieee.

[10] Heri Sunaryo. 2008. Teknik Pengelasan Kapal. Jakarta: Direktorat Pembinaan Sekolah Menengah Kejuruan. 